\title{
Chadian Learners'/Users' Preferred Variety(ies) of English
}

\author{
Gilbert Tagne Safotso ${ }^{1} \&$ Ndoubangar Tompté ${ }^{2}$ \\ ${ }^{1}$ Department of Foreign Applied Languages, University of Dschang, Cameroon \\ ${ }^{2}$ Department of English, University of Doba, Chad \\ Correspondence: Gilbert Tagne Safotso, PO Box 282 Dschang, Cameroon. E-mail: gilbertsafotso@gmail.com
}

Received: August 23, 2020 Accepted: October 3, 2020 Online Published: October 29, 2020

doi:10.5539/ijel.v10n6p410 URL: https://doi.org/10.5539/ijel.v10n6p410

\begin{abstract}
Although French and Arabic are the official languages of Chad, for the past twenty years Chadian learners and users of English have been having a strong interest in the language. Their number in Cameroonian, Nigerian, Ghanaian and Sudanese universities as well as in linguistic centres in N'Djamena testifies to this. It can be said that the petrol boom in the country has really changed the attitudes of Chadians towards English. They see in it the language of opening and opportunities. Given that in most major languages there are accents and variants, and most especially with English the lingua franca of the 21 st century, it is important to know those learners'/users' preferred variety (ies). This paper thus aims to know which variety (ies) of English Chadian learners/users prefer to hear or speak. The data was gathered through a questionnaire administered to 106 university students, 97 secondary school learners, 18 English language teachers and 29 workers of other sectors $(\mathrm{N}=250)$. Results show that most Chadian learners/users prefer American or British English and a good percentage of them favour Ghanaian or Cameroon English.
\end{abstract}

Keywords: varieties, prefer, American English, British English, learner, user

\section{Introduction}

When a language develops into dialects and varieties, its various speakers/users begin to question its various accents or varieties. With English which has become the language of globalisation of the 21st century (Gradol, 2000; Johnson, 2005), the situation is even more complex as the vast majority of its learners/users have never been in contact with native speakers of the Inner Circle varieties that provide the target for language training. They are rather found in the Outer and Expanding Circles (Kachru, 1988). So, when most of those learners/users give judgments on other users' accents or varieties they take as reference what they hear on the radio and television or read in books. The Chadian context where French and Arabic are official languages can be interesting as far as the variety (ies) of English preferred is concerned.

For the past twenty years, Chadian learners and users of English have been having a strong interest in the language. Their number in Cameroonian, Nigerian, Ghanaian and Sudanese universities as well as in linguistic centres in N'Djamena testifies to this (Anderson, 2008; Safotso, 2018; Safotso \& Ndoubangar, 2018). It can be pointed out that the petrol boom in the country has really changed the attitudes of Chadians towards the English language. They see in it the language of opening and opportunities. Given that in all major languages there are accents and variants, and most especially with English the lingua franca of the 21st century, it is important to know those learners'/users' preferred variety (ies). This paper thus aims to know which variety (ies) of English Chadian learners/users prefer to hear or speak.

\section{Brief Presentation of the Situation of English Language in Chad}

The English language does not play a leading role in formal education in Chad since French and Arabic are the two official languages of the country, but it is now taught at all levels of education, and the enthusiasm of many learners to acquire it is real. At Tertiary level, there are already two full departments of English in Chadian universities, namely at the Universities of N'Djamena and Doba. Many linguistic centres in the capital also offer English for Specific Purposes courses to learners who prepare to work with oil companies or to travel to English-speaking countries. In diplomacy, English is the language of transactions between Chad and countries like the USA, Nigeria, Canada, India etc. 


\section{Literature Review}

According to Crystal (2004, p. 16), "Standard English is the variety of English which carries most prestige within a country. Prestige is a social concept; it means some people have high standing in the eyes of others". In the Outer and Expanding Circles, the attitudes towards English accents and varieties are varied. They are generally influenced by the variety of the country where the first English language teachers and teaching materials in the target setting came from. Coskun (2011) studied the attitudes of forty-seven Turkish pre-service teachers and found that, although they considered intelligibility as the central goal of English learning, they said that it is better to teach a normally recognized standard such as American or British English. They disregarded non-native varieties of English as possible alternatives in the ELT classroom. They preferred instructional materials written in American and British English. In Fauzia's and Qismullah's (2009) study, most subjects' attitude towards their own accents in English was positive. However, when asked what varieties of English they liked more, only one of them answered that her own accent was her favourite. The majority of participants opted for British and American varieties. As to the varieties of English they thought should be taught, they declared that 'Standard English' is better as they consider it original and correct English. Thus, it is quite striking to notice that, although speakers are aware of and comfortable with their own accents, they still champion the teaching of native varieties of English. This double-standard approach is what Jenkins (2000) questions when she points out that there is really no justification for doggedly persisting to refer to an item as 'error' if the vast majority of speakers of a given variety of English produce and understand it.

In an interview with eighteen non-native teachers of English about the way they perceive their own accent with regard to the standard, Jenkins (2005) reports that they deemed Standard English good, correct, proficient and competent, and non-native accent poor, incorrect, strong and deficient. Mckay (2003) came to similar findings in his study of the attitudes of Chilean teachers towards EIL. Other studies with similar results include Dalton-Puffer et al. (1997), Timmis (2002), Murray (2003), Mollin (2006). Jenkins (2007) stresses the difficulty teachers have to distinguish between correctness and nativeness, and to assess intelligibility and acceptability not from the native speaker's standpoint. Indeed, most teachers of English feel threatened that the native speaker's accent goal that they have been striving to achieve is no longer the only desirable goal. They are therefore reluctant to accept any model for English language learning that overthrows linguistic 'perfection' as the centre of language learning.

In the literature, little attention has been paid to what prospective teachers, i.e. those who dream to be teachers or are in teacher training schools think about native speaker norms for pronunciation. Yet, that category of teachers is that which, because of globalisation may accept new norms. Ozturk et al. (2009) explored the knowledge, thoughts and beliefs of ten prospective teachers about EIL (English as International Language). The findings indicated that, although the participants acknowledged the status of EIL, they still had norm bound attitudes and considered native speaker models as the ideal goal for teaching. Coskun's (2011) investigation on Turkish subjects led to similar results. The majority of them believed that the goal for pronunciation teaching should be native speaker norms and the ideal pronunciation teacher a native speaker of English.

\section{Method}

The data used come from four categories of subjects: secondary school students (97), university students (106), English language teachers (18) and civil servants (29). The secondary schools involved were Lycée Bernard Dikwa Grandi and Lycée Pascal Yodimmadji of Doba, Lycée Littéraire of Walia and Lycée Sacré-Coeur of N'djamena which are among the major secondary/high schools of Chad. The 97 secondary school learners were made up of 60 boys and 37 girls. Their ages ranged from 16 to 21 years, and the classes concerned were 2 nde (Form 5), Première (Lower Sixth) and Terminale (Upper Sixth). The universities involved were those of N'Djamena and Doba, and the classes targeted were second and third years. The university students chosen were aged between 18 and 23 year's old and comprised 26 girls and 80 boys. The 18 English language teachers were mainly secondary school ones. The civil servants were randomly selected in public services in N'Djamena, Doba and Bongor among those who were fluent in English. They had at least a university level. The four categories of informants were chosen to have a wider view of the problem. They had to answer a questionnaire mediated in English and French for its better understanding (see Appendix A). The first part of the questionnaire aimed to gather the participants' background information and included items such as gender, level of education, travelling abroad/travelling to an English-speaking country experience, radio and TV channels preferences. The second set of questions listed a number of English varieties that the subjects had to tick according to their preferences and to justify their choice (s). In total 250 subjects took part in the survey. The data will be analysed following this order: (1) travelling experience of the subjects, (2) preferred radio and TV stations, (3) English-speaking countries visited, and (4) preferred variety (ies) of English. 


\section{Results}

Since the travelling experiences of the subjects were among the determining factors in knowing their awareness of various English accents, Table 1 below provides an overview of their actual exposure to them.

Table 1. Travelling experiences of subjects

\begin{tabular}{lll}
\hline Travelling background & Number of participants (N=250) & $\%$ \\
\hline I have already travelled to an English-speaking country. & 158 & $63 \%$ \\
I have never travelled to an English-speaking country. & 92 & $37 \%$ \\
I like the way English is spoken there. & 112 & $71 \%$ \\
\hline
\end{tabular}

The table shows that most of the respondents (63\%) have already travelled to an English- speaking country for various reasons including studies, visiting relatives, holidays and business. Indeed, three of Chad neighbouring countries are English-speaking (Cameroon, Nigeria, Sudan). 37\% of the subjects have not yet had the opportunity to travel to any English-speaking country. Concerning the type of English spoken in the countries visited, $71 \%$ of the participants declared that they liked the way people speak it over there. Table 2 which follows summarises the subjects' answers as to their preferred radio stations and TV channels.

Table 2. Participants' preferred radio and television channels

\begin{tabular}{llll}
\hline $\begin{array}{l}\text { Preferred Radio and Television Channels } \\
\text { listened to and watched }\end{array}$ & Number of Subjects $(\mathrm{N}=250)$ & Reason for the choice & $\%$ \\
\hline British Broadcasting Corporation (BBC) & 43 & Native speaker English & 17.2 \\
Voice of America (VOA) & 48 & French/ English courses & 19.2 \\
Cameroon Radio and Television (CRTV) & 71 & It is a bilingual channel & 28.4 \\
CNN & 22 & American way of speaking & 08.8 \\
English Club TV & 66 & To practice English & 26.4 \\
\hline
\end{tabular}

In Table 2, it can be remarked that the first radio and television channel listened to/watched by Chadian learners/users of English is Cameroon Radio and Television (28.4\%). The reason advocated for that choice is its bilingual nature (English and French). English Club TV follows with $26.4 \%$ of the subjects. It is a Chadian local channel where learners of English watch practical English conversations with appropriate pronunciation, i.e., with the native speaker's accent. The channel has series of videos intentionally provided to allow learners to develop their listening and speaking skills. The Voice of America (19.2\%) comes next because it broadcasts English language courses programmes for French-speaking learners. The BBC (17.2\%) is listened to because of its native speaker's accent. CNN (08.8\%) is the least watched channel by Chadian users/learners of English. The reason for that choice is that, as the subjects reported, it is just to listen to the American way of speaking English. Another reason for that small percentage may be due to the fact that the channel is available only to the group of American NGO workers who have the provision of CNN at their work place. So, the majority of the subjects prefer listening to/watching CRTV. This may also be due to the fact that northern Cameroon and southern Chad have many things in common. By listening to and watching Cameroon Radio and Television some of the subjects identify themselves with Cameroonians. Table 3 below lists the countries visited by the subjects.

Table 3. Countries visited by participants

\begin{tabular}{lll}
\hline English-speaking countries visited & Number of subjects $(\mathrm{N}=250)$ & $\%$ \\
\hline America (USA) & 25 & 10 \\
Britain & 04 & 01.6 \\
Cameroon & 98 & 39.2 \\
Canada & 07 & 02.8 \\
China & 02 & 0.8 \\
Ghana & 23 & 09.2 \\
Nigeria & 74 & 29.6 \\
Sudan & 17 & 06.8 \\
\hline
\end{tabular}


The table above reveals that most subjects (39. 2\%) have already travelled to Cameroon for various purposes including business, visiting family members, holidays and studies. The Nigerian destination follows with $29.6 \%$ of the informants. The Cameroonian and Nigerian destinations come first probably because Cameroon and Nigeria are Chad neighbouring countries where its citizens can easily enter with or without a visa. Those two countries are also the main suppliers of Chad via the ports of Douala and Lagos. Many Chadian family members are also scattered in those countries as well as in Sudan. Travelling to the USA (10\%) has become the dream destination of many Chadians. This is because American corporations have been the main oil drilling companies in Chad since 2000s. Ghana (09.2\%) is one of the first four countries visited by the subjects certainly because in West Africa, citizens freely circulate from one country to another without police hassles. The percentage of informants who have travelled to Sudan $(06.8 \%)$ is rather striking. This may be justified by the fact that the country has been in political unrest for the past ten years or so, and is therefore not conducive for studies or business. Though visited just by a marginal number of subjects, it is interesting to note that some have been to Canada (2.8\%), Britain (1.6\%) and China (0.8\%). Canada being a bilingual country, it can be argued that they could speak French there. But it should be pointed out that French is a minority language in that country, and English is heard everywhere. Since the vast majority of Africans who go to China for various purposes do not speak Chinese language, there is a high probability that the informants who visited that country spoke English to interact with Chinese. Indeed, most African students who go to China to study other subjects than Chinese receive their training in English. Given that one cannot interact in the visited countries without being able to speak English, it is interesting to know that the subjects are somehow aware that English varies from one country to another. Table 4 which follows summarises the subjects' preferred variety (ies) of English.

Table 4. Chadian learners'/users' preferred variety (ies) of English

\begin{tabular}{llll}
\hline Preferred variety of English & Number of Subjects (N=250) & Reason for the choice & $\%$ \\
\hline American English & 101 & Lovely and attractive accent & 40.4 \\
Australian English & 00 & - & 00 \\
British English & 72 & Standard English & 28.8 \\
Cameroon English & 22 & Easy to acquire & 08.8 \\
Cameroon Francophone English & 00 & - & 00 \\
Canadian English & 00 & - & 00 \\
Chinese English & 00 & - & 00 \\
Ghanaian English & 31 & Close to British English & 12.4 \\
Liberian English & 00 & - & 00 \\
Nigerian English & 12 & It is a good variety for business. & 04.8 \\
Sudanese English & 07 & It is influenced by Arabic. & 02.8 \\
Other (specify) & 00 & - & 00 \\
\hline
\end{tabular}

Table 4 shows that most Chadian learners/users of English prefer American English (40.40\%). The reason for this preference is the way Americans speak. This quite contradicts their answers to the preferred radio and TV channels (08.8\%). Although the American accent is difficult to the subjects and they have little exposure to it, most of them may prefer American English because they dream to go to America one day. Another reason for preferring that variety may be due to the fact that the US is the country that has many NGOs such the Peace Corps across Chad. Those NGOs volunteers have already taught English to many Chadian children and empowered many villagers. The Americans' presence in oil drilling sites may also justify that choice.

British English (28.5\%) comes second, and the informants justify their choice by saying that it is 'Standard English', i.e. the variety of English that they have been learning in books since primary school. It should be noted that when the Peace Corps volunteers teach in Chadian schools they use didactic materials written in British English. Ghanaian English (12.4\%) is the third variety of English preferred by the informants as they say that it is close to British English. Another reason advocated is that Ghana can be a good place to go to learn English. It is quite surprising to see that the subjects do not quite like Cameroon English (8.8\%) whereas Cameroon Radio Television is their favourite channel (28.4\%). They argue that if they had to learn Cameroon English they would prefer the variety spoken in the northern part of the country where there is no Pidgin English influence. Yet, the variety of English spoken there is rather Cameroon Francophone English that none of them chose. To the participants, Nigerian English (4.8\%) is just good for business (local transactions like trading) and Sudanese English if full of Arabic. 


\section{Conclusion}

To conclude, it clearly appears that Chadian learners/users of English travel to English-speaking countries where they interact with speakers of the varieties of English Spoken there. Cameroon, Nigeria, the US and Ghana are their favourite destinations for several reasons. However, their most preferred varieties of English are rather American English (40.4\%), British English (28.8\%) and somewhat Ghanaian English (12.4\%). It is quite interesting to note that the countries visited or lived in have little or no influence on the preferences. They like American English maybe because of the presence the US in the country through various NGOs and at the oil drilling sites. As to British English, the subjects prefer it because it is the variety of English found in teaching materials and taught at school. As they declare, it is 'Standard English'. This study's findings are not different from those found in early studies for the past 40 years or so (Shaw, 1981; Kachru, 1983, 1986; Dalton-Puffer et al., 1997; Murray, 2003; Mckay, 2003; Mollin, 2006; Ozturk et al., 2009; Coskun, 2011). It simply testifies to the fact that, despite amply documentation and research on New Englishes around the world, they continue have little prestige in the eyes of English as a second or foreign language learners/users compared with native varieties which probably still have a long way to go in the Outer and Expanding Circles. A universal feature of Expanding Circle Englishes might be the way their speakers view British English, American English and Outer Circles varieties.

\section{References}

Anderson, L. (2008). Developmental Expectations of English: Focus on Chad. Unpublished Master's Thesis. Brattleboro, Vermont: School for International Training.

Coşkun, A. (2011). Future English teachers' attitudes towards EIL pronunciation. Journal of English as an International Language, 6(2), 46-68.

Crystal, D. (2004). Rediscover Grammar. Harlow: Pearson Education.

Dalton, P. et al. (1997). Learner Attitudes and L2 Pronunciation in Austria. World Englishes, 16(1), 115-128. https://doi.org/10.1111/1467-971X.00052

Fauzia, D. S., \& Qismullah, Y. (2009). The role of Attitudes and Identity from Nonnative Speakers of English towards English Accents. The English International Language Journal, 4, 110-128. Retrieved from http://www.eltj.com

Graddol, D. (2000). The Future of English-A Guide of Forecasting the Population of English in the 21st Century. Oxford: The British Council.

Jenkins, J. (2000). The phonology of English as an International Language. New Models, New Norms, New Goals. Oxford: Oxford University Press.

Jenkins, J. (2005). Implementing an International Approach to English Pronunciation: The Role of Teacher Attitudes and Identity. TESOL Quarterly, 39(3), 535-543. https://doi.org/10.2307/358849

Jenkins, J. (2007). English as a Lingua Franca: Attitude and Identity. Oxford: Oxford University Press.

Johnson, A. (2005). The Rise of English: The Language of Globalisation in China and the European Union. Macalester International, 22(131), 131-138.

Kachru, B. B. (1983). Models for Non-Native Englishes. In B. Kachru (Ed.), The Other Tongue (pp. 31-54). Oxford: Pergamon Press.

Kachru, B. B. (1986). The Alchemy of English: The Spread, Functions and Models of Non-Native Englishes. Oxford: Pegamon Press.

Kachru, B. B. (1988). Teaching World Englishes. ERIC/CLL News Bulletin, 12(1), 1-4.

Mckay, S. L. (2003). Teaching English as an Intrernational Language: The Chilean context. ELT Journal, 57(2), 139-148. https://doi.org/10.1093/elt/57.2.139

Mollin, S. (2006). Euro-English. Assessing Variety Status. Tübingen: Narr.

Murray, H. (2003). Swiss English Teachers and Euro-English: Attitudes to a non-native variety. Bulletin suisse de linguistique appliquée, 77, 147-165.

Ozturk, H. et al. (2009). How do non-native pre-service English language teachers perceive EIL? A qualitative study. English as an International Language Journal, 5, 137-146.

Safotso, G. T. (2018). A Study of Chadian Learners/Speakers of English Pronunciation. English Language Teaching, 11(10), 1-9. https://doi.org/10.5539/elt.v11n10p1 
Safotso, G. T., \& Ndobangar, T. (2018). Attitudes and Motivation of Chadian Learners of English. World Journal of Education, 8(2), 174-180. https://doi.org/10.5430/wje.v8n2p174

Shaw, W. (1981). Asian students' attitudes towards English. In L. E. Smith (Ed.), English in Cross-cultural communication (pp. 108-122). London: Macmillan. https://doi.org/10.1007/978-1-349-16572-8_8

Timmis, I. (2002). 'Native-Speakers' Norms and International English: A Classroom View. ELT Journal, 56, 240-249. https://doi.org/10.1093/elt/56.3.240

\section{Appendix A}

\section{Questionnaire}

\section{Chadians' Learners/Users of English Preferred Variety(ies) of English}

\section{Part I: Personal background information}

Instruction: Complete or tick the appropriate answer/Complèter ou cocher la réponse correcte.
1) Gender/sexe: male/homme ( ) female/femme ( )

2) Faculty/Faculté/Lycée

3) How long have you been studying English? Depuis combien de temps apprenez-vous l'anglais?..................................

4) Have you ever travelled abroad? Avez-vous déjà voyagé hors de votre pays? Yes/Oui ( ) No/Non ( )

a. If yes, where? $\mathrm{Si}$ oui, où?.................... Purpose of the journey/Raison de votre voyage ...........................................................

b. Was it in an English-speaking country?/Le voyage était-il dans un pays d'expression anglaise? ...Which one?/Lequel? ?

c. Did you like the way they spoke and wrote English there?/Avez-vous aimé la façon dont on parlait et écrivait l'anglais là-bas?

Why/Pourquoi?.

5) Do you watch TV programs or films in English?/Regardez-vous des programmes de télévision ou des films en anglais?.

6) Which TV channels or types of films? Quelles chaines de télévision ou types de films? Why/Pourquoi?

7) Do you like the way journalists and actors speak on those TV Channels? Aimez- vous la façon dont les journalistes et les acteurs parlent sur ces chaines de télévision? Why/Pourquoi?

8) Have you ever been in contact with/Avez-vous déjà été en contact avec

a. An American? Un Américain? ?

b. A British? Un britannique? ?

c. A Canadian? Un Canadien?

d. An Australian? Un Australien?

e. An English-speaking Nigerian? Un Nigerian d'expression anglaise?

f. An English-speaking Cameroonian? Un Camerounais d'expression anglaise?

g. An English Speaking Sudanese? Un Soudanais d'expression anglaise?

h. Any English-speaking person (specify his origin)? Une personne quelconque d'expression anglaise (spécifiez son origine)?

Did you like the way they speak English? Why?

\section{Part II: Preferences for varieties of English}

In the first box put an $\mathbf{X}$ against the varieties of English you prefer to learn or speak. In the second give the reasons why you prefer it/them. Dans la première colonne mettez une croix $\mathbf{X}$ devant la/les variété(s) d'anglais 
que vous préfèrerez étudier ou parler. Dans la deuxième colonne donnez les raisons pour lesquelles vous préférez cette ou ces variétés d'anglais.

\begin{tabular}{l}
\hline Variety of English/Variété d'anglais \\
\hline British English \\
American English \\
Canadian English \\
Australian English \\
Cameroon English \\
Cameroon Francophone English \\
Nigerian English \\
Ghanaian English \\
Sudanese English \\
Chinese English \\
Liberian English \\
Indian English \\
Others (specify)
\end{tabular}

\section{Copyrights}

Copyright for this article is retained by the author, with first publication rights granted to the journal.

This is an open-access article distributed under the terms and conditions of the Creative Commons Attribution license (http://creativecommons.org/licenses/by/4.0/). 